\title{
Otopark Seçim Davranışlarını Etkileyen Faktörler: İzmir Örneği
}

\author{
Mervegül UYSAL ${ }^{1}$ \\ Yalçın ALVER ${ }^{2}$
}

ÖZ

Çalışmada, İzmir ilinin en merkezi bölgelerinden birisi olan Alsancak bölgesinde iki yol kenarı otoparkı ve iki kapalı otoparkı kullanan sürücülerin davranışları incelenmiştir. Sürücülere sosyoekonomik özelliklerinin, yolculuk bilgilerinin ve otoparkları neden tercih ettiklerinin sorulduğu bir anket yardımıyla veriler toplanmıştır. Otoparklarda kalma süreleri ile bu süreleri etkileyen bağımsız değişkenlerin neler olduğu tespit edilmeye çalışılmıştır. Analizlerde ikili logit model kullanılmıştır. Yapılan gözlemlerle otoparkların doluluk oranları ve zirve saat işgal oranları tespit edilmiştir. Otopark seçimini etkileyen faktörler tespit edilmiştir.

Anahtar Kelimeler: Otopark seçim davranışı, yol kenarı parklanma, kapalı otopark, logit model.

\begin{abstract}
Factors Affecting Parking Choice Behaviors: The Case of Izmir

In the study, the parking behavior of drivers using two on-street car parks and two parking garages has been investigated in Alsancak. Alsancak is one of the most central regions of Izmir Province. Data were collected with the help of a survey asking drivers about their socio-economic characteristics, travel information and, why they prefer parking lots. This study tried to determine the duration of parking and the independent variables affecting parking lot choice. The binary logit model was used in the analysis. Utilization rate and peak hour occupancy of parking lots were determined with the help of observations. Factors affecting parking choice selection behaviours have been identified.
\end{abstract}

Keywords: Parking choice behaviour, on-street parking, multi-storey car park, logit model.

\footnotetext{
Not: Bu yazı

- Yayın Kurulu'na 9 Temmuz 2020 günü ulaşmıştır. 17 Haziran 2021 günü yayımlanmak üzere kabul edilmiştir.

- 31 Temmuz 2022 gününe kadar tartışmaya açıktır.

- https://doi.org/10.18400/tekderg.766468

1 Muğla Sitkı Koçman Üniversitesi, İnşaat Mühendisliği Bölümü, Muğla - merveguluysal@mu.edu.tr https://orcid.org/0000-0002-6482-1436

2 Ege Üniversitesi, İnşaat Mühendisliği Bölümü, İzmir - yalcin.alver@ege.edu.tr https://orcid.org/0000-0002-9833-4505
} 


\section{GíRiş}

Otoparkların kapasitesinin yeterince etkili kullanılmaması ve park alanlarının yetersiz olmasından dolayı, park etmek isteyen araçların oluşturduğu trafik yolları işgal etmektedir. Ayrıca, mevcut park alanlarının yetersiz koşullarından dolayı, sürücüler zamanlarının büyük bir bölümünü araçlarına uygun park yeri aramak için harcamaktadırlar [1]. Sürücülerin park yeri aramak için kaybettikleri zamanın yanı sıra, bu "arama trafiği" genellikle büyük şehir merkezlerinde mevcut trafiğe eklenerek, trafik problemlerinin artmasına neden olmaktadır [2]. Bu yüzden, park problemleri genellikle bir döngü problemi ve kentsel ulaşım sistemi içerisinde sürücülerin park etme gereksinimlerinin yeterli bir şekilde karşılanamamasından kaynaklanan olumsuz etkiler olarak ele alınmaktadır [1].

Kutlu [3], özellikle çalışanların çok uzun süreler araçlarını park ettiklerini belirtmiştir. Alışveriş için gelen sürücüler daha kısa süreli parkları tercih etmektedir. Bu yüzden Kutlu, iş yolculukları ve alışveriş yolculukları için ayrı park alanlarının oluşturulması gerektiğini önermiştir. Özdirim [4], bir aracın gün içerisinde en fazla iki saat yolculuk halinde olduğunu belirtmiştir. Bu süre bir aracın gün içerisindeki hareket süresinin \%8'ine karşılık gelmektedir. Şehir içi trafik ile ilgili yapılan çalışmalarda, araçların yolculuk halinde geçirdiği bu süreler dikkate alınmaktadır. Ancak çalışmalar yapılırken araçların park halinde bulunduğu süreler göz ardı edilmektedir. Bununla birlikte, araçların uygun bir park alanı bulmak için harcadıkları süre, park halinde bulundukları süreden 12 kat daha fazladır. Bu sebeple otopark çalışmaları büyük önem kazanmaktadır.

Sürücülerin park alanı seçim davranışlarının tespit edilmesi, park alanlarının tasarımı ve işletmelerinin değerlendirilmesi için önemlidir [5]. Ayrıca şehir merkezlerindeki park problemlerini çözebilmek içinde, sürücülerin seçim davranışlarını bilmek gerekmektedir. Birçok araştırmacı çalışmalarında, sürücülerin park alanı seçim davranışlarını incelemiştir [5-9].

Hongzhi vd., ile Yong park alanı için ödenen ücret ve park alanı seçimi arasında güçlü bir ilişki olduğunu bulmuşlardır [10-11]. Hess [12] tarafından yapılan bir çalışmada ise, yolculuk amaçlarının park alanı seçim davranışlarını etkilediği belirtilmiştir. Yapılan bir başka çalışmada ise altı farklı park alanı incelenmiştir. Çalışmada veriler turistik bir bölge olan Beijing Lama Tapınağı'nda bir anket çalışması yardımıyla toplanmıştır ve park seçim davranışını etkileyen faktörler tespit edilmeye çalışılmıştır. Yürüme mesafesi ile park etme ücretlerinin otopark seçim davranışını etkileyen parametreler olduğu tespit edilmiştir. Ancak park etme süresi ve yürüme mesafesi karşılaştırıldığında sürücülerin yürüme mesafesi konusunda daha hassas oldukları ve park etme ücretlerinin göz ardı edilebileceği belirtilmiştir [5]. Ibeas vd. [6] üç farklı (ücretli ve ücretsiz yol kenarı park alanları ile yeraltı katlı otoparkı) tip park alanı için sürücülerin davranışlarını incelemişlerdir. Çalışmaya göre, İspanya'da, park alanı seçim davranışı ile araçların yaşı, varış noktasına ulaşana kadar ve park alanı bulana kadar geçen süre ile park alanı ücreti arasında, güçlü ilişsiler bulunduğu tespit edilmiştir. Almanya ve İngiltere'de sürücülerin park seçim davranışlarının incelendiği çalışmada ise park ücreti ve yolculuk amacının park seçim davranışını etkilediği tespit edilmiştir [7]. Teknomo ve Hokao [8] etkili bir park etme politikası geliştirmek amacıyla park alanı seçiminde sürücülerin davranışlarını tespit etmeye çalışmışlardır. Çalışmalarında üç farklı park alanı seçim modeli geliştirmişlerdir. Erişilebilir boş park alanı, yolculuk amac1, arama süresi, yürüme süresi, park ücreti, güvenlik ve rahatlık modellerin sonucunda park alanı seçme davranışını etkileyen faktörler olarak bulunmuştur. Kobus vd. [9] 
çalışmalarında park etme ücretlerinin yol kenarı ve kapalı otoparkları seçme davranışını etkileyip etkilemediği araştırılmıştır. Yol kenarı park etme fiyatlarındaki çok az bir düşüşün bile yol kenarı park etme davranışını tetikleyerek yol kenarı park alanlarındaki stoku artıracağı tespit edilmiştir. Khaliq vd. [13] araç sürücülerinin yol kenarı otopark seçim davranışlarını incelemiş̧lerdir. Park ücreti, beklenen park süresi, hız sınırı, park kolaylığı, otopark alanı dışındaki çevre aktiviteleri gibi değişkenlerin seçim davranışını etkilediğini tespit etmişlerdir.

Ülkemizde de otoparklar ile ilgili çalışmalar yapılmıştır. Bu çalışmalarda genellikle otopark sorunları ele alınmıştır. Gülhan ve Ceylan [14] yaptıkları çalışmada, İzmir ili’nin Konak ve Karşıyaka ilçelerinde park yönetim stratejileri için çeşitli çalışmalar ve analizler yapmışlardır. Çalışmada modern parklanma ve yeni park yönetim stratejileri üzerinde durulmuştur. Dönmez vd. [15] Safranbolu kentsel sit alanı için otopark sorunlarını incelemişlerdir. Çalışmada turistik bir bölge olan çarşı bölgesinde bulunan otoparklarda gözlemler yapılarak mevcut sorunlar ve yetersizlikler incelenmiştir. Ceylan vd. [16] Tekirdağ ili Süleymanpaşa ilçesinde bir otopark yönetim çalışması yapmışlardır. Çalışmalarında yol kenarı otopark sistemlerinin trafik dolaşımına etkileri incelenmiştir. Otopark etütleri yardımıyla mahalle bazında otopark ihtiyaçları tespit edilmiştir. Yol kenarı otoparkların doğru işletilmesi ve yol kenarı parklanmanın yapılacağı yolun geometrisinin yeterli olduğu durumlarda bu otopark tipinin trafik dolaşımını etkilemediği tespit edilmiştir. Haldenbilen vd. [17] Denizli ilinde yol dişı otoparkları incelemişlerdir. Bu otoparkların kapasiteleri ve doluluk oranları tespit edilerek geleceğe yönelik otopark ihtiyacını tahmin etmeye çalışmışlardır.

Scheiner vd. [18] hane halkı anketleri ile Almanya'nın Dortmund kentinde bulunan tarihi bir mahallede bulunan park yerlerini incelemişlerdir. Çalışmalarında özel park yerlerinin bulunması durumu ve mesafelerini, yol kenarı park yerlerinin kullanımını, park yeri arama sürelerini ve kullanıcıların memnuniyetini araştıran sorular sormuşlardır. Çalışmanın sonucunda yasal olarak bir ücretlendirme veya kısıtlama olmayan yol kenarı parklarda özel park yerlerine gereksinimin bulunmadığı tespit edilmiştir. Ayrıca park yeri arama sürelerinin ve yol kenarına park etmiş araçlara olan mesafenin aslında algılanandan daha düşük olduğu tespit edilmiştir. Mevcut özel park yerleri gerektiği gibi kullanıldığı takdirde yasadışı parklanmanın \%28 ila \%49 oranında azaltılabileceği öngörülmüştür. Wang vd. [19] fiyatlandırmanın, park süresinin ve sirkülasyon oranının, yol kenarı parklardaki park etme davranışına olan etkisini araştırmışlardır. Çalışmada Nanning'de yeni bir fiyatlandırma politikası yürürlüğe girmeden önce ve sonra dört farklı zaman diliminde toplanan panel verileri kullanılmıştır. Önce ve sonra çalışması için Kolmogorov-Smirnov testleri yapılmıştır. Yazarlar park fiyatı arttıkça park etme süresinin azaldığını tespit etmişlerdir. Sirkülasyon hızındaki değişikliğin ise araç sahipliği ile ilişkili olacağı varsayımında bulunmuşlardır. Çalışmada ayrıca yol kenarı parklarda yeni bir fiyatlandırma politikasının park etme davranışını etkilediği tespit edilmiştir.

Atalay ve İçen [20] Elazığ ilinde otopark ihtiyacının araştırılması için çalışma yapmışlardır. Kent merkezinde bulunan yol dışı otoparklar ve yol kenarı parklar mevcut yönetmeliklere göre incelenmiştir. Park etüdü çalışmaları iki hafta süreyle yapılmıştır. Çalışma sonucunda mevcut otoparkların yetersiz olduğu, otoparkların tasarım problemlerinin olduğu gözlemlenmiştir. Yol kenarı parklarda ise park etme açısının değiştirilmesinin kapasiteyi artıracağı tespit edilmiştir. 
Şenbil ve Yetişkul [22] İstanbul ili için, sokakların serbest otopark alanları olarak kullanımı araştırmışlardır. Bu çalışmada park etme davranışlarının analizinin yapılması ve otopark politikalarının geliştirilmesi amaçlanmıştır. Yol kenarı, bina içi ve ücretli parklanma olmak üzere üç farklı gece parklanma türü için hanehalkı seçimleri dikkate alınarak çok seçmeli logit model ile analizler yapılmıştır. Eğer otopark politikaları arazi kullanımı ve kullanıcıların park etme davranışlarına göre yapılmazsa, park problemlerinin ilerleyen dönemlerde çözülemeyen bir hale gelebileceği tespit edilmiştir.

Bu çalışmada İzmir ili, Alsancak bölgesinde, iki yol kenarı park alanı ve iki kapalı otopark incelenerek otopark seçim davranışlarını etkileyen faktörler tespit edilmeye çalışılmıştır. Özellikle araçların park halinde geçirdiği süreler üzerinde durulmuştur. Yine gözlem süresince otoparkların doluluk oranları ve zirve saat işgal oranları tespit edilmiştir.

\section{VERILLERIN TOPLANMASI VE ANALIZİ}

Bu çalışmada, Alsancak bölgesi çalışma alanı olarak seçilmiştir. Bu bölge birçok hastane, iş merkezi, otel, spor merkezi ve ibadethane barındırmaktadır ve İzmir için turistik bir bölgedir. Ayrıca bu bölge, İzmir'in en eski yerleşim yerlerinden birisidir ve birçok tarihi alan yer almaktadır. Tarihi yapıların ve eski yerleşim yerlerinin çok olmasından dolayı, Alsancak'ta yeteri kadar yol ve otopark yapılması mümkün olmamaktadır. Ayrıca kent merkezlerinde yolların genişletilmesi ve otopark sayısının artırılması, özel araç trafiğini artıracağı için ulaşım planlamasında tercih edilen bir yaklaşım değildir.

Alsancak bölgesi, çok yoğun bir şekilde kullanıldığı için otoparkların iyi yönetilmesine ihtiyaç duyulmaktadır. Bölgede otopark gereksinimi; binaların kendi otoparklarıyla, İzelman'ın (İzmir Büyük Şehir Belediyesi'ne ait otopark şirketi) işlettiği otoparklarla veya kural dışı yola park etme ile çözülmeye çalışılmaktadır. Çizelge 1'de çalışmada incelenen park alanlarının özellikleri ve ücretlendirme bilgileri yer almaktadır.

Çizelge 1 - Park alanlarının özellikleri

\begin{tabular}{|c|c|c|c|c|c|c|c|}
\hline Otopark & \multicolumn{5}{|c|}{ Saatlik Ücretlendirme } & Tür & Kapasite \\
\hline \multicolumn{8}{|c|}{$0-12$ saat } \\
\hline $\begin{array}{l}\text { Sezer Doğan } \\
\text { Sokak }\end{array}$ & \multicolumn{5}{|c|}{$7,50 \mathrm{TL}$} & $\begin{array}{c}\text { Yol } \\
\text { kenar1 }\end{array}$ & 50 araç \\
\hline $\begin{array}{l}\text { Cumhuriyet } \\
\text { Bulvarı }\end{array}$ & \multicolumn{5}{|c|}{$7,50 \mathrm{TL}$} & $\begin{array}{c}\text { Yol } \\
\text { kenar1 }\end{array}$ & 142 araç \\
\hline \multirow{2}{*}{ Kahramanlar } & $0-4$ saat & $\begin{array}{c}4-8 \\
\text { saat }\end{array}$ & $\begin{array}{l}8-24 \\
\text { saat }\end{array}$ & $\begin{array}{l}\text { 19:00- } \\
09: 00\end{array}$ & $\begin{array}{l}\text { Aylık } \\
\text { Abone }\end{array}$ & \multirow{2}{*}{ Kapalı } & \multirow{2}{*}{1264 araç } \\
\hline & $4,00 \mathrm{TL}$ & $\begin{array}{l}8,00 \\
\text { TL }\end{array}$ & $\begin{array}{l}12,00 \\
\text { TL }\end{array}$ & $4,00 \mathrm{TL}$ & $100 \mathrm{TL}$ & & \\
\hline \multirow[t]{2}{*}{ Kültürpark } & $\begin{array}{l}0-12 \\
\text { saat }\end{array}$ & & aat & $\begin{array}{l}\text { 19:00- } \\
09: 00\end{array}$ & $\begin{array}{l}\text { Aylık } \\
\text { Abone }\end{array}$ & \multirow[t]{2}{*}{ Kapalı } & \multirow[t]{2}{*}{594 araç } \\
\hline & $7,50 \mathrm{TL}$ & & & $5,00 \mathrm{TL}$ & $240,00 \mathrm{TL}$ & & \\
\hline
\end{tabular}


Çalışma kapsamında iki adet yol kenarı otoparkı seçilmiştir. Bu otoparklar Sezer Doğan Sokak üzerinde ve Cumhuriyet Bulvarı'nda yer alan İzelman'a ait yol kenarı parklardır. Sezer Doğan Sokak yol kenarı parkının bulunduğu sokakta hastane, oteller, iş merkezleri ve konutlar bulunmaktadır. Cumhuriyet Bulvarı'nda yer alan yol kenarı parkında, yolun her iki tarafında ve orta refüjde iki sıra olmak üzere toplam dört sıra halinde park edilmektedir. Konum olarak Kordon'a ve Kıbrıs Şehitleri Caddesi'ne yakın olmakla birlikte çevresinde iş merkezleri, eğlence mekânları, alışveriş merkezleri, sağlık tesisleri bulunmaktadır. Aynı zamanda çalışmada aynı bölgede bulunan iki adet kapalı otopark incelenmiştir. Bu otoparklar ise, bölgenin en büyük otoparkı olan Kahramanlar Katlı otoparkı ve Kültürpark yer altı otoparkıdır (Şekil 1). Kahramanlar Katlı otoparkında hali hazırda işletilen bir ring sistemi bulunmaktadır.

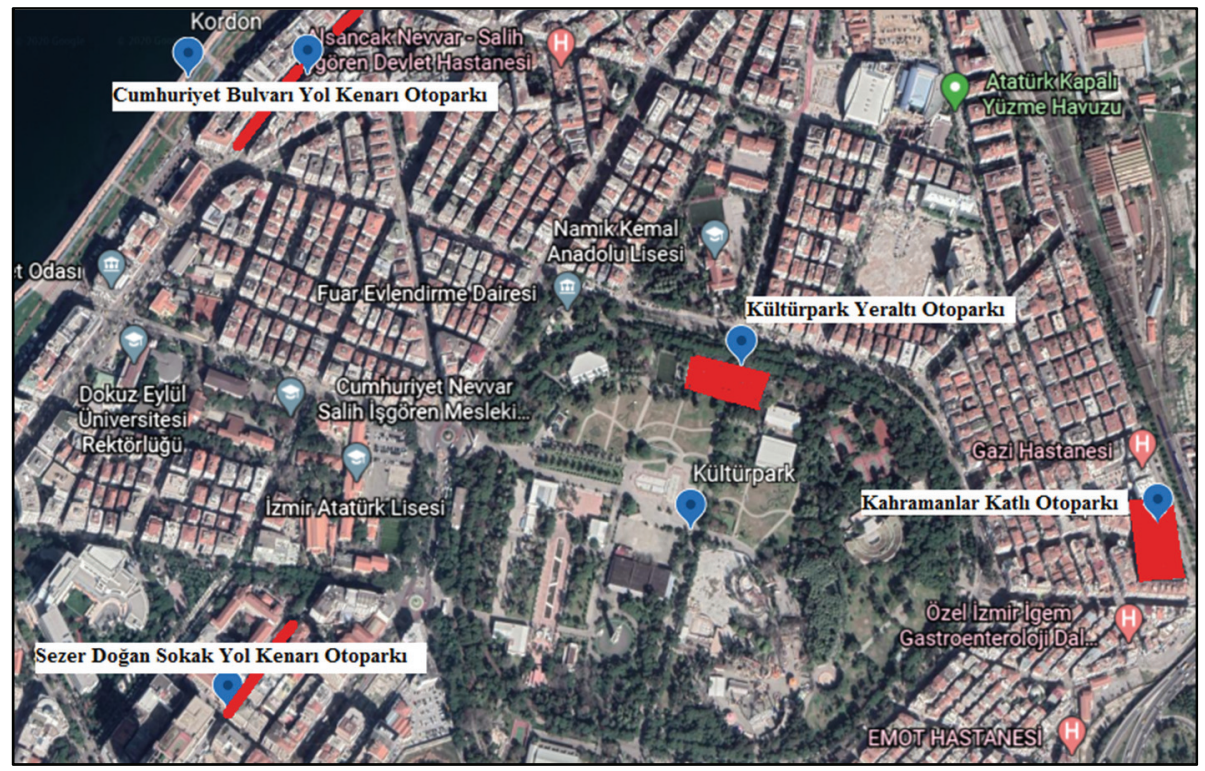

Şekil 1 - Incelenen otoparklar

Çalışmada yüz-yüze anketlerden elde edilen veriler yanında otoparklarda yapılan araç sayımlarından elde edilen veriler de kullanılmıştır. Kahramanlar ve Kültürpark otoparklarında 22 Şubat-16 Mart tarihlerinde hafta içi 07.30-18.00 saatleri, hafta sonu ise 08.00-16.00 saatleri arasında toplam 402 anket yapılmıştır ve toplamda 2895 araç sayılmıştır. Yol kenarı otoparkları için ise 24 Mart-16 Şubat 2017 tarihleri arasında kapalı otoparklar için seçilen saatler ile aynı saatlerde toplam 303 adet anket yapılmıştır ve toplam 830 araç sayılmıştır. Anketler gelişigüzel (rastgele) örneklem seçim tekniği kullanılarak toplanmıştır. Bu teknikte örneklem hiçbir ölçüt kullanılmadan toplanmaktadır. Bu teknikle toplanan verilerin ana kütleyi ne kadar temsil ettiği ya da ana kütleden ne kadar farklılaştığ1 tam olarak bilinememektedir. Buna ek olarak yaklaşık anket sayılarının bilinebilmesi için, ana kütledeki eleman sayısı bilinemediği durumlarda kullanılan Denklem 1'e göre hesaplamalar yapılmıştır. 


$$
n=\frac{t^{2} p q}{d^{2}}
$$

Burada, $n$ örneklem sayısını, $p$ olayın görülüş sıklığını, $t \mathrm{t}$ tablosundan alınan değeri, $q$ olayın görülmeyiş sıklığını ve $d$ ise olayın görülüş sıklığına göre sapmasını temsil etmektedir. Gözlem süresince sayılan araç sayısına göre hesaplar yapıldığında analiz edilecek örneklem sayısı 30'un altında kalmaktadır. Bu yüzden ana kütlenin bilinmediği duruma göre örneklem hesabı yapılmıştır. Ana kütle bilinmediği için serbestlik derecesi sonsuz olarak alınmıştır. Güven aralığı \%95 olarak kabul edilmiştir. 0,05 güven aralığı ve sonsuz serbestlik derecesinde $\mathrm{t}$ tablosundan bulunan değer 1,96 olarak elde edilmiştir. $\mathrm{Bu}$ veriler 1şı̆̆ında incelenecek veri sayısı Denklem 1'e göre 384 olarak hesaplanmıştır. Bu sonuca göre toplanan verilerin analizlerde kullanmak için yeterli olduğu tespit edilmiştir.

Yapılan anketlerin ilk beş sorusunda sürücülerin sosyoekonomik ve demografik özellikleri, altıncı ve yedinci sorularda yolculuklarının başlangıç ve varış noktaları, sekizinci soruda yolculuk amaçları, dokuzuncu soruda yolculuk süreleri, sonraki iki soruda ise katılımcılara kaç kişi yolculuk ettikleri ve otoparkı tercih etme nedenleri sorulmuştur. Bu sorulardan sonra yol kenarı otoparkları ve kapalı otoparkları kullanan sürücülere sorulan sorular farklılık göstermektedir. Yol kenarı otoparklar için yapılan ankette, saatlik ücretlendirme politikası, Kahramanlar kapalı otoparkında kullanılan ring sisteminden haberlerinin olup olmadığı ve bu otoparkı kullanmak isteyip istemedikleri, kapalı otoparklar için ise, otoparkta kalma süresi, otopark ücreti fazla olsa yine tercih edip etmeme durumu, abonelik, ring güzergâh memnuniyeti, ring kullanan sürücülerin hangi durakta indikleri ve ne sıklıkta ring kullandıkları sorulmuştur. Ayrıca otoparkların giriş ve çıkışlarına kameralar yerleştirilerek araçların giriş- çıkış saatleri ile kaç adet aracın giriş yaptığı sayılmıştır. Eksik verisi bulunan anketler çalışmaya dâhil edilmemiştir. Çalışmada veriler toplanırken herhangi bir ölçek kullanılmamıştır. Toplanan veriler ile ilgili bilgiler Çizelge 2'de verilmiştir.

Çalışmaya toplam 211 kadın, 494 erkek katılmıştır. Kadın sürücülerin 115'i yol kenarı otoparkları, 96'sı ise kapalı otoparkları tercih etmiştir. Yapılan anket çalışmasına göre, yol kenarı otoparkları en çok kullanan yaş grubunun 30-39 yaş aralığındaki sürücüler olduğu tespit edilmiştir. Ankete katılan sürücülerden Cumhuriyet Bulvarı'nda bulunan yol kenarı otoparkı kullanan sürücülerin \%77'si bu yaş grubundadır. Bu değer Sezer Doğan Sokak için \%42 olarak bulunmuştur. İncelenen kapalı otoparkları en çok kullanan yaş grubu ise kendi içinde değişiklik göstermiştir. Kahramanlar katlı otoparkını kullanan sürücülerin \%37'si yol kenarı otoparklarda olduğu gibi 30-39 yaş grubunda olmasına rağmen, Kültürpark yer altı otoparkını kullanan sürücülerin \%42’si 40-49 yaş grubundadır.

Anket çalışmasında otoparkları kullanan sürücülere eğitim durumları sorulmuştur. Çizelge 2'ye göre incelenen tüm otoparklarda, otoparkları kullanan sürücüler içerisinde en büyük pay eğitim durumu üniversite olan sürücülere aittir. Eğitim durumu üniversite olan sürücülerin, ankete katılan tüm sürücülerin \%57'sini oluşturduğu belirlenmiştir.

İncelenen tüm otoparklarda iş yolculuğu en büyük paya sahiptir. Cumhuriyet Bulvarı'nda gezi/eğlence yolculuğu yapan sürücüler ikinci en büyük paya sahiptir. Bu durum Sezer Doğan Sokak'ta ise sağlık yolculuğu olarak değişkenlik göstermiştir. Kahramanlar katlı otoparkında sağlık yolcuğu, Kütürpark yer altı otoparkında ise gezi/eğlence yolculuğu 
ikinci en büyük paya sahip yolculuk amaçları olarak tespit edilmiştir. Kahramanlar katlı otoparkını ve Kültürpark yer altı otoparkını kullanan sürücülerin özellikle hafta içi büyük çoğunluğunun iş ve sağlık amaçlı yolculuk ettikleri tespit edilmiştir. $\mathrm{Bu}$ da otopark etrafında var olan sağlık kuruluşları sebebi ile tercih ettiklerinin göstergesidir. Doluluk oranlarının detayları Çizelge 2'de verilmiştir.

Çizelge 2 - Anket sonuçları

\begin{tabular}{|c|c|c|c|c|c|c|c|}
\hline & & $\begin{array}{c}\text { Cumhuriyet } \\
\text { Bulvarı }\end{array}$ & $\begin{array}{l}\text { Sezer } \\
\text { Doğan } \\
\text { Sokak }\end{array}$ & $\begin{array}{c}\text { Yol } \\
\text { Kenarı } \\
\text { Toplam }\end{array}$ & $\begin{array}{c}\text { Kahramanlar } \\
\text { Katlı Otoparkı }\end{array}$ & $\begin{array}{c}\text { Kültürpark } \\
\text { Yeraltı } \\
\text { Otoparkı }\end{array}$ & $\begin{array}{c}\text { Kapalı } \\
\text { Otopark } \\
\text { Toplam }\end{array}$ \\
\hline \multirow{2}{*}{ Cinsiyet } & Erkek & $98(\% 55)$ & $90(\% 73)$ & 188 & $192(\% 82)$ & $114(\% 68)$ & 306 \\
\hline & Kadın & $81(\% 45)$ & $34(\% 27)$ & 115 & $42(\% 18)$ & $54(\% 32)$ & 96 \\
\hline \multirow{5}{*}{ Yaş } & $18-29$ & $44(\% 25)$ & $28(\% 23)$ & 72 & $37(\% 16)$ & $14(\% 8)$ & 51 \\
\hline & $30-39$ & $77(\% 43)$ & $52(\% 42)$ & 129 & $86(\% 37)$ & $61(\% 36)$ & 147 \\
\hline & $40-49$ & $44(\% 25)$ & $26(\% 21)$ & 70 & $49(\% 21)$ & $70(\% 42)$ & 119 \\
\hline & $50-59$ & $6(\% 3)$ & $7(\% 6)$ & 13 & $34(\% 14)$ & $18(\% 11)$ & 52 \\
\hline & $60+$ & $8(\% 4)$ & $11(\% 8)$ & 19 & $28(\% 12)$ & $5(\% 3)$ & 33 \\
\hline \multirow{5}{*}{ Gelir } & -Asg. Ücret & $21(\% 12)$ & $17(\% 13)$ & 38 & $6(\% 3)$ & $10(\% 6)$ & 16 \\
\hline & Asg. Üc.-2500 TL & $17(\% 9)$ & $25(\% 21)$ & 42 & $47(\% 20)$ & $19(\% 10)$ & 66 \\
\hline & 2500 TL-3500 TL & $46(\% 26)$ & $45(\% 37)$ & 91 & $122(\% 52)$ & $58(\% 35)$ & 180 \\
\hline & 3500 TL-5000 TL & $50(\% 28)$ & $17(\% 13)$ & 67 & $38(\% 16)$ & $57(\% 35)$ & 95 \\
\hline & $5000 \mathrm{TL}+$ & $45(\% 25)$ & $19(\% 16)$ & 64 & $21(\% 9)$ & $24(\% 14)$ & 45 \\
\hline \multirow{5}{*}{ Eğitim } & İlkokul & $0(\% 0)$ & $5(\% 4)$ & 5 & $7(\% 3)$ & $3(\% 2)$ & 10 \\
\hline & Ortaokul & $12(\% 7)$ & $20(\% 16)$ & 32 & $12(\% 5)$ & $0(\% 0)$ & 12 \\
\hline & Lise & $50(\% 28)$ & $36(\% 29)$ & 86 & $72(\% 31)$ & $45(\% 26)$ & 117 \\
\hline & Üniversite & $102(\% 57)$ & $58(\% 47)$ & 160 & $127(\% 54)$ & $112(\% 67)$ & 239 \\
\hline & Lisansüstü & $15(\% 8)$ & $5(\% 4)$ & 20 & $16(\% 7)$ & $8(\% 5)$ & 24 \\
\hline \multirow{5}{*}{ Meslek } & Serbest Meslek & $28(\% 16)$ & $18(\% 15)$ & 46 & $16(\% 7)$ & $23(\% 14)$ & 39 \\
\hline & Özel Sektör & $115(\% 64)$ & $75(\% 61)$ & 190 & $177(\% 76)$ & $126(\% 75)$ & 303 \\
\hline & Emekli & $11(\% 7)$ & $13(\% 10)$ & 24 & $34(\% 15)$ & $7(\% 4)$ & 41 \\
\hline & Öğrenci & $17(\% 9)$ & $10(\% 8)$ & 27 & $3(\% 1)$ & $3(\% 2)$ & 6 \\
\hline & İşsiz & $8(\% 4)$ & $8(\% 6)$ & 16 & $4(\% 1)$ & $9(\% 5)$ & 13 \\
\hline \multirow{5}{*}{$\begin{array}{l}\text { Yolculuk } \\
\text { Amacı }\end{array}$} & İş & $72(\% 40)$ & $51(\% 41)$ & 123 & $146(\% 62)$ & $79(\% 47)$ & 225 \\
\hline & Eğitim & $14(\% 8)$ & $15(\% 12)$ & 29 & $3(\% 1)$ & $8(\% 5)$ & 11 \\
\hline & Sağlık & $20(\% 11)$ & $31(\% 25)$ & 51 & $39(\% 17)$ & $20(\% 12)$ & 59 \\
\hline & Alışveriş & $39(\% 22)$ & $11(\% 9)$ & 40 & $21(\% 9)$ & $12(\% 7)$ & 33 \\
\hline & Gezi/Eğlence & $33(\% 18)$ & $16(\% 13)$ & 49 & $25(\% 11)$ & $49(\% 29)$ & 74 \\
\hline
\end{tabular}

Şekil 2'de incelenen otoparklarda yolculuk amaçlarına göre otoparktan varış noktasına olan yürüme mesafeleri verilmiştir. Sezer Doğan Sokak'ta bulunan yol kenarı otoparkına araçlarını park eden sürücülerin varış noktalarına olan ortalama yürüme mesafeleri 117,3 
metre olarak hesaplanmıştır. Cumhuriyet Bulvarı'ndaki yol kenarı otoparkı için ise bu değer 147,5 metredir. Kahramanlar katlı otoparkında ortalama yürüme mesafesi 320 metre, Kültürpark yer altı otoparkında ise bu değer 667 metre olarak bulunmuştur. Yapılan gözlemlere göre, yolculuk amaçlarının yürüme mesafesi üzerinde etkili olduğu tespit edilmiştir. Sezer Doğan Sokak'ta bulunan yol kenarı otoparkına en çok iş ve sağlık amaçlı yolculuklar yapılmıştır. Sürücülerin özellikle sağlık amaçlı yolculuklarında araçlarını gidecekleri sağlık merkezine en yakın noktaya park etmek istedikleri görülmüştür. Sürücüler gezi/eğlence ve alışveriş amaçlı yolculuklarında ise araçlarını varış noktalarına daha uzak bir yere park etmeyi kabul etmektedirler.

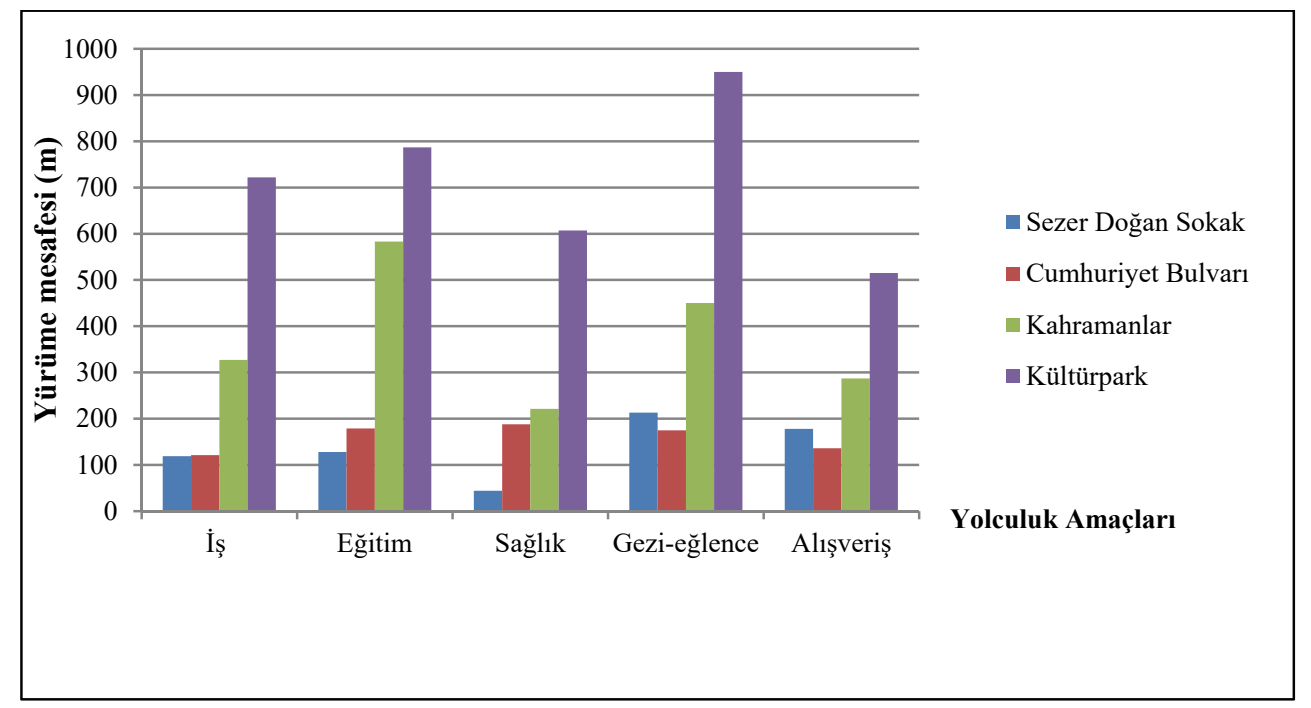

Şekil 2 - Yolculuk amaçlarına göre yürüme mesafeleri

Kahramanlar katlı otoparkında bir ring sistemi olduğu çalışmada daha önce belirtilmiştir. Kahramanlar katlı otoparkından hareket eden dört adet ücretsiz servisle bu sistem işletilmeye başlanmıştır. Servisler 07.00-23.00 saatleri arasında hafta içi ve Cumartesi günleri 10 dakika, Pazar günleri ise 30 dakika arayla sefer yapmaktadır. Başlangıç noktası Kahramanlar katlı otoparkı olan bu servisler, Kültürpark yer altı otoparkına uğrayarak Gündoğdu Meydanı'na ulaşmaktadır. Servisler bu noktadan geri dönerek Alsancak tam otomatik otoparkı ve Alsancak yeraltı otoparkına uğramaktadır. Servisler bu noktadan sonra tekrar Kahramanlar katlı otoparkına gelerek bir döngüsünü tamamlamaktadırlar. Şekil 3 'te ring sisteminin durakları ve güzergâhı verilmiştir.

$\mathrm{Bu}$ çalışmada ankete katılan sürücülerin $\% 35$ 'i ring sitemini kullanan kişilerdir. Ring sistemini kullanan kişilerin \%88'i Kahramanlar katlı otoparkını tercih etmişlerdir. Kahramanlar katlı otoparkını tercih eden ve ring sistemini kullanan sürücülerin ineceği duraklar ile varış noktalarına yürüme mesafeleri incelenmiştir. Ring sistemini kullanan sürücülerin yürüme mesafesi ortalama 254 metre, ring sistemini kullanmayan sürücülerin yürüme mesafesi ise ortalama olarak 580 metre olarak hesaplanmıştır. 


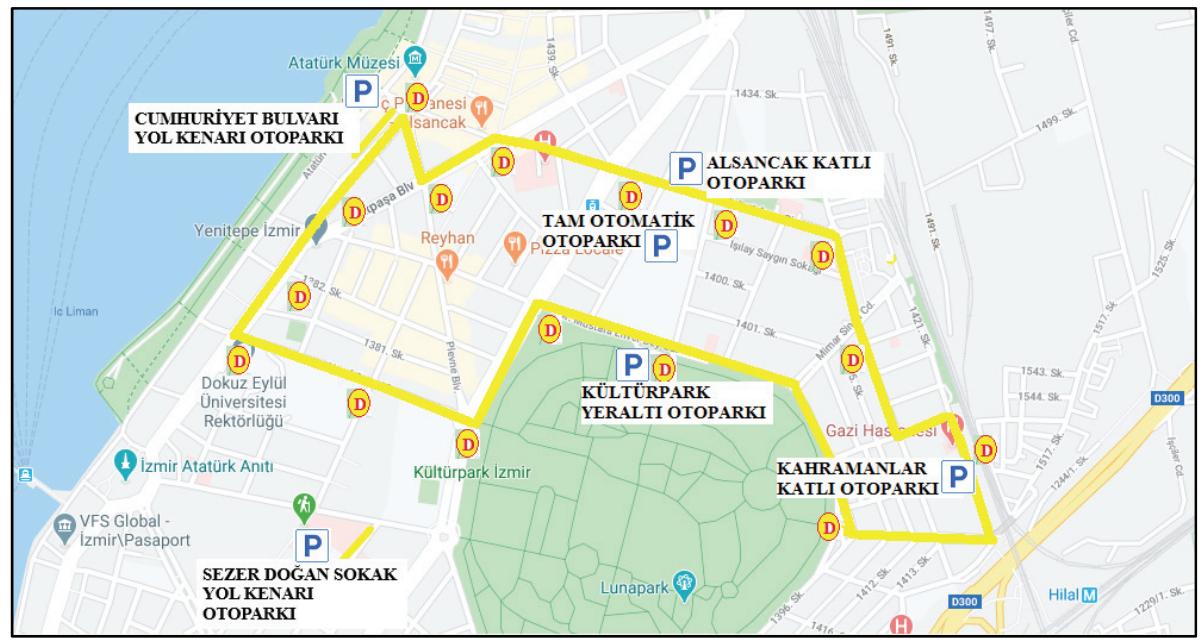

Şekil 3 - Ring sistemi güzergâhı

Anket çalışmasında incelenen yol kenarı otoparkları kullanan sürücülere, ring sisteminden haberdar olup olmadıkları sorulmuştur. Bu otoparkları tercih eden sürücülerden 194'ü (\%64) ring sisteminden haberinin olduğunu, 109'u (\%36) ise haberinin olmadığını belirtmiştir. Ayrıca sürücülere daha uygun park etme ücretine sahip Kahramanlar katlı otoparkını kullanıp, ücretsiz ring sistemini kullanmak isteyip istemeyecekleri sorulmuştur. Bu soruya sürücülerin $\% 50,5$ 'i “evet", $\% 49,5$ 'i "hayır" cevabını vermiştir.

Veriler toplanırken araçların otoparklarda kalma süreleri de dikkate alınmıştır. Kapalı otoparkların giriş ve çıkışlarına, yol kenarı otoparklarında yolun başı ve sonuna, yüksek üç ayaklar üzerine kameralar kurulmuştur. Elde edilen giriş ve çıkış görüntülerinden araçların plakaları eşleştirilerek kalma süreleri belirlenmiştir. Yol kenarı otoparklar için ortalama kalma süresi 171 dakikadır. Sezer Doğan Sokak'ta bulunan yol kenarı otoparkını kullanan sürücülerin ortalama kalma süreleri 129 dakika, Cumhuriyet Bulvarı yol kenarı otoparkı için bu süre 199 dakika olarak tespit edilmiştir. Kültürpark yer altı otoparkında araçların ortalama park etme süresi 187 dakika, Kahramanlar katlı otoparkında ise bu süre 173 dakikadır. Kapalı otoparklarda ise ortalama kalma süresi 180 dakikadır. Aşağıda verilen şekilde incelenen tüm otoparklar için toplam otoparkta kalma süreleri gösterilmiştir (Şekil 4).

Çalışma kapsamında anket verilerinin toplanmasına ek olarak otoparka giren ve çıkan araç sayımları da yapılmıştır. İncelenen kapalı ve açık otoparklar için araç sayımlarından otopark doluluk oranları tespit edilmiştir, bunun için, iki tür hesaplama yapılmıştır. İncelenen otoparkların zirve saatlerdeki işgal edilme yüzdesi ile gözlem yapılan süre boyunca otoparkların doluluk oranları belirlenmiştir. Zirve saatlerdeki işgal edilme yüzdeleri hesaplanırken, sabah zirve saatleri (07:30-09:30) dikkate alınmıştır. Şekil 5'te elde edilen sonuçlar yer almaktadır. Bu sonuçlara göre Sezer Doğan Sokak'ta bulunan yol kenarı otoparkı kapasitesinin çok üstünde çalışmaktadır. Aynı sokakta bir çocuk hastanesi 


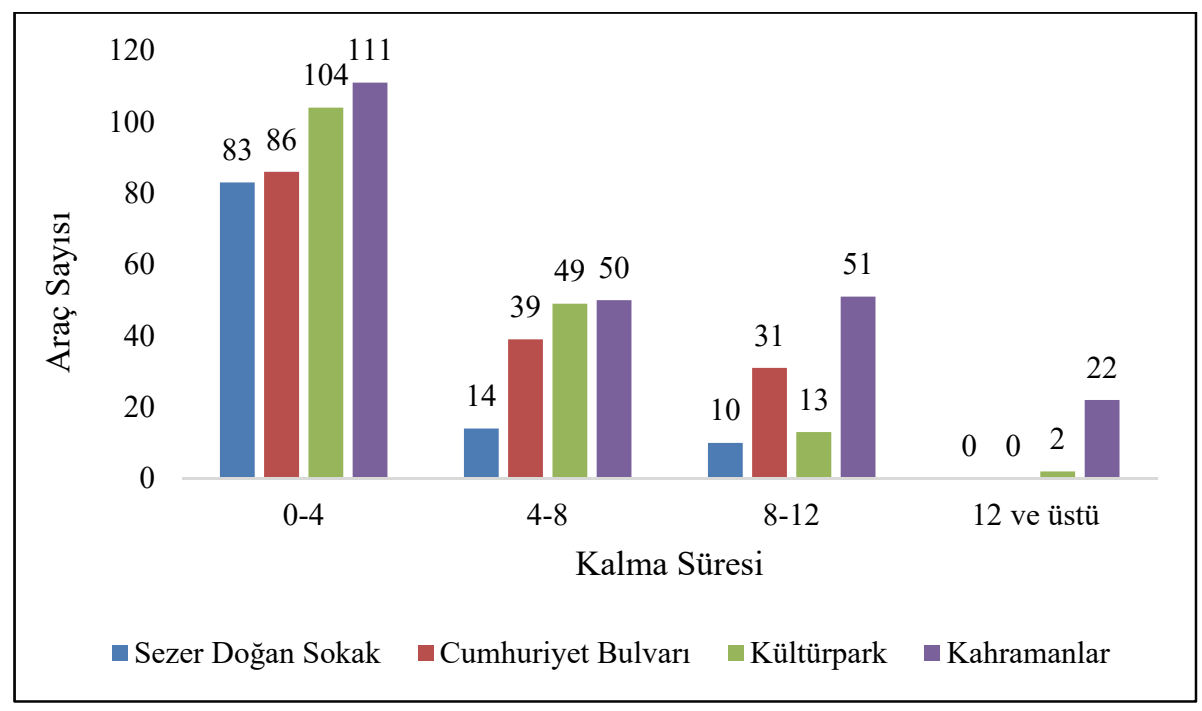

Şekil 4 - Araç sayllarına göre otoparkta kalma süreleri

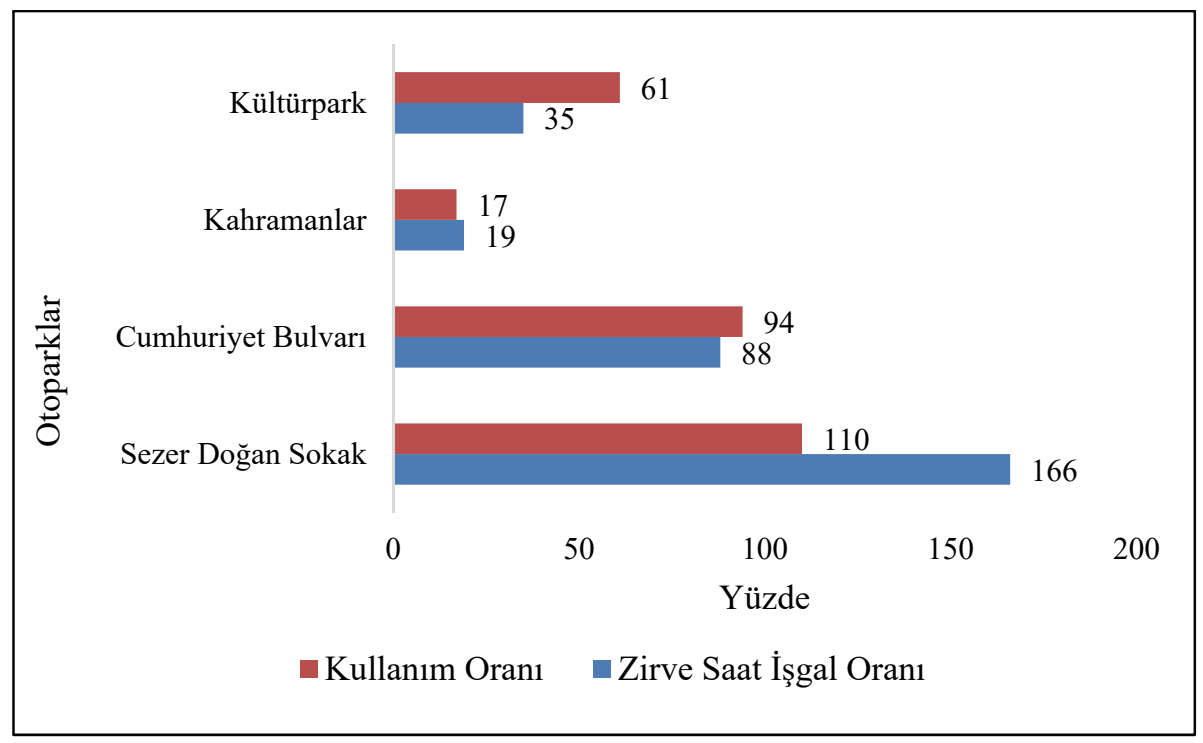

Şekil 5 - Otopark doluluk oranlarl

bulunduğu için, sabah zirve saatlerinde kısa süreli parklar gözlemlenmiştir. Bu yoğunluk sebebi ile sabah zirve saatler için yapılan hesaplamalarda bu otoparkın kapasitesi \%166 değerinde, yani kapasitesinin 1,66 katı kadar bir işgal oranı ile hizmet vermeye çalışmaktadır. Aynı zamanda gözlem yapılan süre boyunca yine bu otopark için sirkülasyon 
oranı yaklaşık 4 olarak bulunmuştur. Bu oran bize bu otoparkta bulunan bir park yerinin gözlem boyunca $4 \mathrm{kez}$ işgal edildiğini göstermektedir. Kahramanlar Katlı otoparkı, zirve saatlerde \%19 değerinde işgal oranı ile hizmet vermektedir. Çalışma süresince bu otoparkın doluluk oranı \%17 olarak bulunmuştur. Çizelge 2'de verildiği üzere bu otoparkı kullanan sürücülerin \%62'si iş yolculuğu amacı ile burada bulunmaktadır. Otopark kapasitesine göre yapılan işlemler sonucunda hem zirve saat işgal oranı hem de gözlem süresince doluluk oranları birbirine yakın bulunmuştur. Başka bir değişle, zirve saatlerde araçlarını bırakıp ring sistemiyle işyerlerine ulaşan sürücüler, gözlem süresince araçlarını burada bırakmaktadırlar. Otoparkı kullanan sürücüler genelde iş yolculuk amacı ile bu otoparka geldikleri için, hesaplanan bu iki değer birbirleriyle uyumlu çıkmıştır.

\section{YÖNTEM}

Logit modeller regresyon analizinin bir tipidir. Bu modellerde amaç, bağımlı değişken kategori olasılıklarını, modeldeki bağımsız değişkenler yardımıyla açıklamaktır. Bunun için çalışmada ikili logit model kullanılmıştır. İki seçenek arasından bir seçim yapılması istendiğinde kullanılan seçim yöntemi ikili lojit model adını almaktadır. Bu durumda seçenekler için oluşturulan kümede iki seçenek bulunmaktadır [21].

Sürücülerin park etme sürelerine göre kapalı otoparkları ya da yol kenarı otoparkları seçme davranışları, formülü Denklem (2) ve (3)'te verilen logit modeller [21] yardımıyla belirlenmeye çalışılmıştır.

$U_{j i}=\beta_{j i}^{\prime} x_{j i}+\varepsilon_{j i}$

$P_{i}(j)=\frac{e^{\beta \prime_{i} x_{i}}}{1+e^{\beta{ }^{\prime} x_{i}}}$

Burada $U_{j i}$, j. alternatif için i. karar vericinin faydasını, $\beta_{j i}^{\prime}$ tahmin edilen katsayılar vektörünü, $x_{j i}$ değişkenleri, $\varepsilon_{j i}$ ise hata vektörünü temsil etmektedir. Denklem (3), i. karar vericinin $\mathrm{j}$. alternatifi seçme olasılığını vermektedir.

Bu çalışma için Seçenek I 'Dört saat altı park etme süresi' iken Seçenek II 'Dört saat üstü park etme süresi olarak belirlenmiştir. Yapılan çalışmanın fayda fonksiyonu ise Denklem (4)'te verildiği gibidir.

$\mathrm{U}=-682 \mathrm{SDS}-0,505 \mathrm{CB}+0,79 \mathrm{KP}-1,591$ Yaş4 $-1,2$ Yaş5 - 0,475Gelir4 - 0,617İş 1,368Ĕgitim + 0,581Sağlık + 0,001Yürümes + 0,635Tekkişi

\section{BULGULAR VE TARTIŞMALAR}

Çizelge 3'te park etme süreleri göz önüne alınarak yapılan ikili logit model sonuçları yer almaktadır. Modelde bağımlı değişken olarak otopark kullanım süreleri kabul edilmiştir. Dört saat altı ve üstü olarak, otoparklarda park etme süreleri gruplandırılmıştır. Referans kategori ise dört saatin altında park etme olarak belirlenmiştir. İkili logit model yardımıyla otoparklarda park etme sürelerini etkileyen faktörler tespit edilmeye çalışılmıştır. 
Tablolarda bulunan işaretin yönü çıkan sonucun bağımlı değişkenin o parametreden ne yönde etkilediğini göstermektedir. Başka bir deyişle negatif çıkan bağımsız değişkenler (1. Sütun) bağımlı değişkeni (park süresinin dört saatin altında olması) ters yönde etkilemektedir.

Çizelge 3 - Park etme sürelerine göre ikili logit model sonuçlarl

\begin{tabular}{|c|c|c|c|c|c|c|}
\hline \multirow{2}{*}{ Bağımlı Değişken:Park etme süresi } & \multirow{2}{*}{ B } & \multirow{2}{*}{ S.E } & \multirow{2}{*}{ df } & \multirow{2}{*}{ Sig. } & \multicolumn{2}{|c|}{$\% 95$ C.I } \\
\hline & & & & & Min. & Maks. \\
\hline Sezer Doğan Sokak & $-0,682$ & 0,303 & 1 & 0,025 & $-2,12$ & $-0,153$ \\
\hline Cumhuriyet Bulvarı & $-0,505$ & 0,277 & 1 & 0,058 & $-1,652$ & $-0,125$ \\
\hline Kültürpark & 0,79 & 0,253 & 1 & 0,001 & 0,292 & 1,287 \\
\hline $50-59$ yaş & $-1,591$ & 0,574 & 1 & 0,006 & $-0,965$ & 0,148 \\
\hline 60 yaş ve üzeri & $-1,2$ & 0,462 & 1 & 0,009 & $-2,108$ & $-0,293$ \\
\hline $3500 \mathrm{TL}-5000 \mathrm{TL}$ & $-0,475$ & 0,232 & 1 & 0,041 & $-0,931$ & $-0,019$ \\
\hline İş amac1 & $-0,617$ & 0,226 & 1 & 0,006 & $-1,061$ & $-0,173$ \\
\hline Eğitim amacı & $-1,368$ & 0,049 & 1 & 0,005 & $-2,324$ & $-0,412$ \\
\hline Sağlık amacı & 0,581 & 0,271 & 1 & 0,032 & 0,048 & 1,115 \\
\hline Yürüme mesafesi & 0,001 & 0 & 1 & 0,038 & 0,015 & 1,001 \\
\hline \multirow[t]{5}{*}{ Tek başına yolculuk } & 0,635 & 0,219 & 1 & 0,004 & 1,112 & 1,887 \\
\hline & Örneklem sayısı : 675 & & & & & \\
\hline & Loglikelihood $_{0}:-411,48$ & & & & & \\
\hline & R.loglikelihood: 618,36 & & & & & \\
\hline & McFadden R2 : 0,6108 & & & & & \\
\hline
\end{tabular}

Çizelge 3'e göre yol kenarı parkların kısa süreli parklar için daha çok tercih edildiği tespit edilmiştir. Bunun sebebinin bu yol kenarı parklardan birisinin bir hastane önünde bulunması, diğerinin ise gezi, alışveriş ve dinlenme merkezlerine yakın bir konumda bulunmasıdır. 50 yaş üstü sürücülerin dört saat ve daha fazla sürelerde park ettikleri bulunmuştur. Analiz sonuçlarına göre orta gelirli sürücüler dört saat üstü park etmiştir. İş ve eğitim amaçlı yolculuklarda sürücüler uzun süreli park ederken, sağlık amaçlı yolculuklarda sürücüler kısa sürekli park etmeyi tercih etmiştir. Yürüme mesafesi arttıkça sürücülerin daha uzun süreli park ettikleri tespit edilmiştir. Aynı şekilde tek başına yapılan yolculuklarda sürücüler daha uzun süreli park etmişlerdir. Bu yüzden tek başına yolculuk yapan sürücülerin çoğunlukla iş ve eğitim amaçlı yolculuk yapan sürücüler olduğu düşünülmektedir. Analiz sonuçlarına göre sürücülerin eğitim durumlarının ve cinsiyetlerinin park etme davranışına etki etmediği tespit edilmiştir. 


\section{SONUÇLAR}

Bu çalışmada İzmir ili Alsancak bölgesinde bulunan ikisi yol kenarı ikisi kapalı otopark olmak üzere dört farklı otopark kullanıcılarının otopark seçim davranışları incelenmiştir. Veriler yüz yüze anketler yapılarak ve araç sayımları ile toplanmıştır. Çalışmada otoparkların doluluk oranları da tespit edilmiştir. Sezer Doğan Sokak'ta bulunan yol kenarı otoparkın kapasitesinin \%166'sı oranında çalıştığ tespit edilmiştir. Bu otoparkın bulunduğu sokakta bir hastanenin bulunması ve çeşitli iş merkezlerine yakın olmasından dolayı bu otoparkın çok kullanıldığı belirlenmiştir. Kahramanlar katlı otoparkında bulunan ring sistemine bir güzergâh daha eklenerek veya mevcut ring güzergâhına bir durak daha eklenerek Sezer Doğan Sokakta bulunan yol kenarı otoparkından geçirilmesi bu otoparkın doluluk oranını normal seviyelere düşürebilir. Aynı şekilde bu düzenlemeyle birlikte kapasitesinin çok altında çalışan Kahramanlar Katlı otoparkının doluluk oranı artırılabilir.

Anket verilerinden elde edilen sonuçlara göre kadın sürücülerin en çok tercih ettiği otoparkın Cumhuriyet Bulvarı yol kenarı otoparkı olduğu görülmektedir. Bunun sebebinin kadın sürücülerin incelenen yol kenarı otoparklarında kendilerini daha güvende hissetmesi olarak düşünülmektedir. Aynı zamanda bu otopark Kordon'a ve burada bulunan eğlence ve alışveriş noktalarına oldukça yakın bir yerde bulunmaktadır. Bu yüzden özellikle kadın sürücülerin, park ücreti ve park etme rahatlığını göz ardı ederek kendilerini güvende hissettikleri otoparkları tercih ettikleri düşünülmektedir. Bu yüzden kapalı otoparkların kameralarla güvenliğinin artırılması, otopark içi aydınlatmaların iyileştirilmesi gerekmektedir. Bu otopark, yukarıda da belirtildiği gibi sahil kesimine ve gençlerin yoğun olarak ziyaret ettikleri merkezlere yakın olduğu için, genç ve orta yaşlı sürücülerin bu bölgeye gittiklerinde araçlarını bu otoparka park ettikleri düşünülmektedir.

Kahramanlar otoparkını seçen sürücülerin varış noktalarına uzun yürüme mesafeleri olduğu belirlenmiştir. Bu otoparkta bulunan ring sisteminin Şekil 3'te gösterildiği gibi geniş bir güzergâhı vardır. Sürücüler varış noktalarına yaklaştıkça, trafik yoğunluğundan ve yeterli araç park alanının mevcut olmamasından dolayı, park yeri aramak için araç içerisinde oldukça uzun süreler geçirmektedirler. Kahramanlar katlı otoparkı, daha uzakta olmasına rağmen ring sistemine sahip olmasından dolayı sürücüler bu otoparkı seçmektedirler. Başka bir deyişle sürücüler uygun bir park etme alanı arayarak geçireceği süre yerine ring sistemini kullanarak varış noktalarına daha kısa sürede gitmeyi tercih etmektedirler. Literatüre göre yürüme mesafeleri arttıkça sürücülerin kapalı otoparkları seçme olasılıkları artmaktadır [9]. Bu sonuç Kobus ve arkadaşlarının [9] yaptıkları çalışmanın sonuçlarına paraleldir. Kapalı otoparklara park etme, ortalama olarak, son varış noktasına daha uzun bir yürüme mesafesi gerektirdiğinden, bir sürücü kapalı otoparka daha uzun süre park edecektir.

Kültürpark yer altı otoparkı incelenen bölgenin merkezinde yer almasına rağmen bu otoparkı kullanan sürücülerin varış noktalarına olan yürüme mesafeleri fazladır. Sürücülerin varış noktalarına yürüme mesafesi artsa bile park etme kolaylığından bu otoparkı seçtikleri düşünülmektedir. Bunun sebebi özellikle uzak yerlerden gelen sürücülerin çok fazla park yeri aramak ve yoğun trafiğe girmek istememesidir.

Elde edilen sonuçlara ek olarak Kültürpark yeraltı otoparkı, İzmir fuar alanı içerisinde bulunmasından ve içerisinde yürüyüş alanları, kafeler ve eğlence merkezlerinin yer 
almasından dolayı bu otoparkı tercih eden sürücülerin hafta sonları da kalabalık gruplar halinde gezi/eğlence için bu otoparkı tercih ettikleri söylenebilir.

Kent merkezinde bulunan kapalı otoparkların, incelenen sürücülerin varış noktalarına daha uzakta bulunmasından dolayı tam kapasitelerinde kullanılamadığ otoparkların ücretlendirilmesi saatlik olarak düzenlenerek, uzun süreli parklar için sürücüler kapalı otoparkları kullanmaya teşvik edilebilir. Aynı şekilde kapalı otoparklar için 0-12 saatlik olarak daha uygun bir ücretlendirme düzenlenirse, bu otoparklar daha efektif olarak kullanılabilir. Özellikle yol kenarı otoparkların kısa süreli parklar için düzenlenmesi, şehir merkezlerinde önemli bir trafik problemi olarak karşımıza çıkan kural dışı parklanmaların önüne geçilmesine yardımcı olabilir.

Otoparkların bulundukları konumların, sürücülerin seçim davranışlarını etkilediği gözlenmiştir. Otopark seçim davranışları hafta içi ve hafta sonu olmasına göre değişkenlik göstermemiştir. Otoparkların anket verilerine göre hafta içi büyük ölçüde iş ve sağlık yolculuk amaçları için, hafta sonları ise gezi/eğlence ve alışveriş yolculuk amaçları için kullanıldığı tespit edilmiştir. Dolayısıyla hafta içi ve hafta sonu yoğunluğuna göre ayrı park politikalarının geliştirilmesi ile mevcut park etme ve trafik problemlerinin üstesinden gelinebilir.

Çalışma, incelenen otoparklar özelinde İzmir ilinde bulunan sürücülerin otopark seçim davranışlarının tespitini amaçlamıştır. Otopark problemleri büyük ölçüde göz ardı edilen bir problem olduğu için bu makale literatürdeki bu eksikliği gidermeyi amaçlamıştır. Çalışma, sürücülerin otopark seçim davranışlarının bilinmesi ile ileride düzenlenecek otopark politikalarına veri sağlayabilecek niteliktedir. Gelecek çalışmalarda incelenen otopark sayısı ve otopark seçim davranışını etkileyen değişken sayısı artırılarak çalışma daha ileriye götürülebilir.

\section{Kaynaklar}

[1] Yardım, S., Korkmaz B. ve Yılmaz D., Sürdürülebilir Ulaştırma Politikaları Açısından Otopark Stratejileri, 7th International Congress on Advances in Civil Engineering, ACE 06-210, 2006.

[2] Okubay, M., Bölgesel Otopark Yönetimi ve Stratejileri: Tarihi Yarımada-Eminönü Bölgesi Örneği, Doktora tezi, Yıldız Teknik Üniversitesi, Istanbul, 2008.

[3] Kutlu, K., Trafik Etüdleri, İstanbul Teknik Üniversitesi Yayınları, İstanbul. 1975.

[4] Özdirim, M., Trafik Mühendisliği, KGM, Ankara, 1994.

[5] Ma, X., Sun, X., He, Y., and Chen, Y., Parking Choice Behavior Investigation: A Case Study at Beijing Lama Temple. Procedia-Social and Behavioral Science, 96, 2635-2642, 2013.

[6] Ibeas, A., Dell'Olio, L., Bordagaray, M., and Ortuzar, D., Modelling Parking Choices Considering User Heterogeneity, Transportation Research Part A, 70, 41-49, 2013.

[7] Axhausen, W., K., Polak, and W., J., Choice of Parking: Stated Preference Approach Transportation, Kluwer Academic Publisher, Hollanda, 1991. 
[8] Teknomo, K., and Hokao, K., Parking Behavior in Central business Districy a Study case of Surabaya, Indonesia, Journal of EASTS, 2, 551-570, 1997.

[9] Kobus, M., Puigarnau, E., Rietveld, P., and Ommeren, J., The On-street Parking Premium and Car Drivers' Choice Between Street and Garage Parking, Regional Science and Urban Economics, 43, 395-403, 2013.

[10] Hongzhi, G., and Lanhui, L., Survey and Analysis of Parking Behavior in Metropolitan Business Quarter, Journal of Beijing Polytechnic University, 2003.

[11] Yong, Y., and Min, L., Research on Relationship Between Parking-charge and Parking Behavior in CBD, Journal of Hebei University of Technology, 37, 110-114, 2008.

[12] Hess,S., and Polak,J.W., An Analysis of Parking Behavior Using Discrete Choice Models Calibrated on SP Datasets, R-Sessions At The European Regional Science Conference, Porto, 2004.

[13] Khalid, A., Waerdan, P., Janssens, D., and Wets, G., A Conceptual Framework for Forecasting Car Driver's On-Street Parking Decisions, Transportation Research Procedia, 37, 131-138, 2019.

[14] Gülhan, G., ve Ceylan, H., Otopark Sorununa Otopark Yönetimi Temelinde Yaklaşımlar: İzmir Örneği, DEÜ Mühendislik Fakültesi Mühendislik Bilimleri Dergisi, 12, 63-73, 2010.

[15] Dönmez, Y., Çabuk, S., Öztürk, M., ve Gökyer, E., Safranbolu Kentsel Sit Alanında Otopark Sorunu ve Çözüm Alternatifleri, Bartın Orman Fakültesi Dergisi, 18(2), 137 $145,2016$.

[16] Ceylan, H., Gulhan, G., Ceylan H., ve Haldenbilen, S., Kentlerimizde Yol Kenarı Otopark Yönetim Stratejilerinin Trafik Dolaşımı Açısından Değerlendirilmesi: Süleymanpaşa İlçesi, Tekirdağ Örneği, TMMOB İnşaat Mühendisleri Odası, 12. Ulaştırma Kongresi (Ulaştırma Politikaları) Bildiriler Kitabı, 59-70, 2017.

[17] Haldenbilen S., Murat, Y.Ş., Baykan, N., ve Meriç, N., Kentlerde Otopark Sorunu: Denizli Örneği, PAJES, 5(2-3), 1099-1108, 1999.

[18] Scheiner J., Faust N., Helmer J., Straub M., and Holz-Rau C., What's That Garage For? Private Parking and On-Street Parking in a High-Density Urban Residential Neighbourhood, Journal of Transport Geograpy, 85, 1-14, 2020.

[19] Wang H., Li R., Wang X., and Shang P., Effect of On-Street Parking Pricing Policies on Parking Characteristics: A Case Study of Nanning, Transportation Research Part A: Policy and Practice, 137, 65-78, 2020.

[20] Atalay A., ve İçen Y., Kentiiçi Otopark Analizi: Elazığ İli Örneği, Fırat Üniversitesi Mühendislik Bilimleri Dergisi, 32(3), 403-413, 2020.

[21] Train, K.E., Discrete Choice Methods with Simulation, Cambridge University Pres, New York, 2009.

[22] Şenbil M., ve Yetişkul E., İstanbul için Gece Parklanma Davranışları Modellemesi, İMO Teknik Dergi, 27 (3), 7515-7532, 2016. 
